\title{
PEKERJA DI SEKTOR PERDAGANGAN PADA EKONOMI SKALA KECIL DESA CATURTUNGGAL DEPOK SLEMAN
}

\author{
Oleh: Alip Sontosudarmo
}

\section{ABSTRACT}

The purpose of this study is to elaborate the workers of trade sector in economy at micro scale in Caturtunggal village, Depok Subdistric, Sleman Regency. Trade sector in economy at micro scale has become interesting, because not only the productivity has increase, but also the workers.

The result of this research reveal that the trade sector absorb the workers not only who came from this village, but who come from outsider as well. This trade is classifield (1) bousebold business (2) permanent business, (3) traveling salesman. Based on this classification, it's clear that most of the workers in bousebold business, and permanen business are the people who live in this village (67\%), meanwhile, most of traveling salesman come jrom outsider (68\%). Two third of The Workers in this trade is women.

Most of them concentrated on bousebold business and permanent business. Based on the age of the workers, it obirons that The Workers on permanent business older than the workers on bousebold business and traveling salesman. More than a balf of workers on trade business consist of the outsiders.

The strategies that is used to increase the income are prolon bours and the amount of the workers. Altbough these strategies weren't profitable, it must be done. Therefore, the produclivity of this business still lower. It can be showed on their income.

\section{INTISARI}

Penelitian ini membabas pekerja di sektor perdagangan pada ekonomi skala kecil di Desa Caturtunggal, Kecamatan Depok, Kabupaten Sleman. Sektor perdagangan pada ekonomi skala kecil menjadi menarik, karena banyaknya pekerja yang dimanfaatkan dan produktivitasnya sampai batas tertentu meningkal pula.

IIasil penelitian mengungkapkan babwa pada sektor perdagangan pada ekonomi skala kecil ini dapat menyerap pekerja pendatang dan pekerja asli Desa Caturtunggal. Dengan membedakan perdagangan menjadi tiga kelompok, yakni usaba rumab tangga, menetap dan keliling, diperoleb bukti babwa perdagangan usaba rumab tangga dan menetap banyak dilakukan pekerju asli Desa Caturlunggal (67 persen) dan pedagang keliling banyak dilakukan oleh para pendatang (68 persen). Dua pertiga pekerja di bidang perdagangan ini terdiri dari wanila. Sebagian besar dari mereka mengelompok pada usaba mumah tangga dan usaba menetap. Dilibat dari usia para pekerja, usaba perdagangan menetap lebib tua dibandingkan dengan usaba rumab tangga dan keliling. Hampir separo pekerja pada usaba perdagangan terdiri dari para pendatang. 
Strategi untuk memperoleb pendapatan yang meningkat usaba perdagangan pada ekonomi skala kecil terpaksa ditempub dengan jalan memperpanjang jumEab jan kerja dan jumlah pekerja yang terlibat. Meskipun bila dilibat dari jumlah satuan jam kerja dan jumlab yang terlibat tidak menguntungkan, namun bal itu kadang-kadang tetap dilakukan, sebingga produktivitas usaba perdagangan pada ekonomi skala kecil tetap rendab tercermin pada pendapatan.

\section{Pengantar}

\section{Latar Belakang Penelitian}

Produktivitas pekerja di sektor perdagangan pada sektor ekonomi skala kecil yang sifatnya padat tenaga kerja sangat penting untuk diketahui. Lingkup pekerjaan itu dapat bersifat sementara sambil menunggu kesempatan yang ada, dapat pula pekerjaan sambilan atau mungkin merupakan pekerjaan utama. Oleh karena itu produktivitas pekerja di sektor perdagangan menjadi penting dalam hubungannya dengan karakteristik kualitas pekerja dalam ekonomi skala kecil

Produktivitas pekerja di sektor perdagangan pada sektor ekonomi skala kecil ini bervariasi dari rendah sampai tinggi, namun karena melibatkan banyak anggota keluarga dalam produksi dan pemasaran hasil penyebabkan usaha ini sulit berkembang. Dalam jangka pendek kegiatan ini dapat menampung tambahan pekerja, namun dalam jang. ka panjang akan timbul masalah berkaitan dengan produktivitasnya. Upaya pengembangan dari usaha perdagang. an pada sektor ekonomi skala kecil semakin rumit karena berbagai jenis usaha terlibat di dalamnya.

\section{Tujuan Penelitian}

Tujuan penelitian dibedakan menjadi dua bagian yang saling berhubungan, yaitu tujuan bersifat umum dan tujuan bersifat khusus. Secara umum penelitian ini bertujuan untuk mengeta- hui kemanfaatan pekerja yang kerja dalam usaha perdagangan pada sektor ekonomi skala kecil, sedangkan secara khusus lebih diarahkan pada penjabaran tujuan umum secara lebih operasional, yaitu:

(1) Untuk mengetahui keterlibatan keluarga pada usaha perdagangan

(2) Untuk mengetahui produktivitas usaha perdagangan dalam hubung. annya dengan jumlah jam dari hari kerja serta pendapatan.

(3) Untuk mengetahui kemanfaatan yang diperoleh serta pengembangan usaha yang telah dilakukan.

\section{Tinjauan Pustaka}

Menurut Forbes (1981:17) analisis ekonomi skala kecil lebih baik dilihat dari cara dan sistem produksi. Kegiatun ekonomi skala kecil ini tercermin juga pada usaha rumah tangga, dengan ciri-ciri: (1) tenaga kerja yang digunakan tidak lebih dari lima, (2) modal usaha tidak lebih dari satu juta rupiah dan (3) cara produksi masih sederhana, bukan mekanis.

Penelitian sektor perdagangan pada ekonomi skala kecil ini mirip dengan sektor informal seperti yang ditulis Ili. dayat (1978:426) yang bercirikan: (1) relatif mudah memasukinya, (2) lebih banyak mengandalkan sumber modal sendiri, (3) merupakan usaha milik ke. luarga, (4) intensitas tenaga kerja padat karya, (5) tidak teratur dalam penggunaan waktu dan tempat bekerja, (6) belum terjangkau oleh kebijaksanaan 
pemerintah, (7) teknologi yang dipergunakan masih bersifat tradisional dan (8) kurang diperlukan pendidikan formal namun diperlukan pengalaman kerja.

Usaha perdagangan telah banyak menyerap tambahan tenaga kerja, seperti halnya dengan sektor ekonomi skala kecil pada umumnya (industri, kerajinan dan perdagangan). Trisura Suradi (1983:21) menyebutkan bahwa semakin banyak dijumpai penduduk yang bekerja secara mandiri atau aktivitas mereka menggunakan pekerja kcluarga. Mereka menciptakan lapangan kerja sendiri tanpa menunggu uluran tangan pemerintah.

IJasil penelitian Sudarsono (1986) di Yogyakarta mengungkapkan bahwa kegiatan ekonomi skala kecil mempunyai peranan yang penting dalam hal: (1) menyerap tenaga kerja yang berlcbih, (2) menunjang perkembangan dan kehidupan sektor formal di kota, dan (4) dapat memenuhi kebutuhan schari-hari yang relatif rendah biayanya, baik kebutuhan akan barang dan jasa.

Hasil lokakarya nasional pembinaan scktor informal tahun 1985 mengemukakan 11 ciri pokok kegiatan scktor informal, yaitu: (1) pola kegiatannya ticlak teratur, (2) tidak tersentuh peraturan pemerintah, (3) skala usahanya kecil menggunakan teknologi sederhana, (4) struktur unit usaha keluarga, (5) umumnya tidak mempunyai unit usaha yang terpisah dari tempat tinggalnya, (6) umumnya dilakukan untuk melayani golongan masyarakat terbatas dan mempunyai daya saing yang tinggi, (7) tidak memerlukan ketrampilan dan keahlian khusus, (8) tidak atau belum mampu memanfaatkan keterkaitan dengan usaha lain sejenis yang lebih besar, (9) bersifat inovatif didasarkan pa- da kebutuhan konsumen terbatas dan mempunyai kekenyalan terhadap perubahan, (10) tidak mengenal sistim perbankan, pembukuan, perkreditan dan pengelolaan usaha yang baku dan (11) dalam melaksanakan kegiatan usahanya lebih didasarkan nilai yang berlaku setempat.

\section{Hipotesis}

Berdasarkan tinjauan pustaka dan landasan teori disajikan lima jenis hipotesis di bawah ini.

1. Jenis usaha perdagangan menetap lebih banyak mengikutsertakan ang. gota keluarga dibandingkan dẹngan jenis usaha perdagangan lainnya.

2. Jenis usaha perdagangan menetap mempunyai tingkat pendapatan yang lebih tinggi dibandingkan dengan jenis usaha perdagangan lainnya.

3. Terdapat hubungan positip antara penghasilan dan jumlah anggota ke luarga yang ikut mencari nafkah.

4. Terdapat hubungan positip antara jam kerja dan penghasilan.

5. Terdapat hubungan negatip antara pendidikan pekerja dengan jumlah anggota keluarga yang ikut mencari nafkah

\section{Cara Penelitian}

Penelitian ini dilaksanakan di Desa Caturtunggal, Kecamatan Depok, Kabupaten Sleman, Daerah Istimewa Yogyakarta. Desa ini banyak ditempati olch Universitas Gadjah Mada, Universitas Atmajaya, Universitas Islam Indonesia, Institut Keguruan dan Ilmu Pendiclikan dan Rumah Sakit Dr. Sardjito. Seiring dengan berkembangnya pusat pendidikan tinggi dan pusat pelayanan kesehatan ini, kegiatan ekonomi skala kecil- 
pun tumbuh dengan pesat pada usaha warung makan, toko-toko dan pedagang keliling. Kegiatan ini dapat berupa usaha rumah tangga, menetap dan keliling. Untuk mencapai tujuan penelitian tersebut di depan, maka pengumpulan data dalam penelitian ini dengan melalui beberapa tahap.

\section{Sensus Rumah Tangga}

Desa Caturtunggal terdiri atas 20 Dusun dan 6 Rukun Kampung (RK). Dari sejumlah Dusun tersebut diambil 9 Dusun yang letaknya berdekatan dengan pusat-pusat pendidikan tinggi dan pusat pelayanan kesehatan. Mengingat 9 Dusun tersebut banyak kegiatan usaha pemondokan atau asrama mahasiswa yang setiap tahun pertambahannya cukup tinggi, maka daerah tersebut berkembang pesat kegiatan perdagangan pada sektor ekonomi skala kecil, baik usaha rumah tangga, menetap maupun berkeliling. Oleh karena itu penelitian ini terbatas pada 9 Dusun terpilih, meskipun tidak tertutup kemungkinan di antara dusun yang tidak terpilih lainnya didapatkan kegiatan perdagangan pada sektor ekonomi skala kecil, namun tidak sebanyak 9 Dusun terpilih tersebut.

Tahap pertama penelitian adalah melaksanakan sensus rumah tangga pada setiap Rukun Tetangga, Rukun Warga dari 9 Dusun secara tidak langsung. Sensus rumah tangga secara tidak langsung karena sensus tersebut tidak langsung mencacah dari rumah ke rumah, namun berdasarkan informasi dan pengamatan dari wilayah rumah tangga yang diperoleh dari Ketua Rukun Tetangga (RT). Mendasarkan pada cakupan wilayah $\mathrm{RT}$ jumlah penduduknya relatif sedikit (+ 50 rumah tangga), maka hasil sensus secara tidak langsung pun diharapkan masih dapat diandalkan kualitasnya. Pada tahap ini diperoleh gambaran tentang rumah tangga beserta kegiatan perdagangan pada sektor ekonomi skala kecil dari tingkat RT, RW maupun pedusunan.

Hasil sensus secara tidak langsung tersebut kemudian dikelompokkan menurut jenis kegiatan perdagangan selama seminggu yang lalu sebelum pénelitian dilaksanakan. Berdasarkan informasi dan pengamatan diperoleh gam. baran tentang rumah tangga yang memiliki kegiatan perdagangan pada sektor ekonomi skala kecil kurang le. bih sebesar 580 rumah tangga. Dari sejumlah rumah tangga tersebut karena biaya tenaga dan waktu yang tersedia tidak semua diwawancarai.

Jumlah responden yang diwawancarai tidak diambil secara proporsional, akan tetapi diambil secara purposive, disesuaikan dengan tujuan penelitian dan analisis data yang mengacu pada unit jenis usaha. Jumlah populasi dan sampel yang diambil menurut pedusunan tercantum pada Tabel 2.1.

\section{Pengumpulan Data}

Data yang dikumpulkan dalam penelitian ini lebih ditekankan pada hasil wawancara dengan responden terpilih di samping memanfaatkan data sekun. der yang diperoleh dari kantor desa dan dusun sampel. Setelah responden terpilih, dilakukan wawancara dengan pedoman kuesioner yang telah diuji cobakan sebelumnya. Kuesioner yang telah disiapkan merekam informasi tentang karakteristik kegiatan ekonomi skala kecil, keadaan sosial budaya, riwayat pekerjaan, pekerjaan sekarang dan intensitas jam keria.

Kegiatan wawancara lapangan clilakukan pada bulan Nopember - Desem. ber 1988 , yang sebagian datanya belum diolah secara terperinci. Diharapkan 
dalam laporan ini diperoleh suatu gam: baran lebih mendalam tentang usaha perdagangan pada sektor ekonomi ska- la kecil, dengan membedakan usaha rumah tangga, menetap dan keliling. 
Tabel 2.1. Jumlah Populasi dan Sampel.

\begin{tabular}{|c|c|c|c|c|c|c|}
\hline \multirow{2}{*}{\multicolumn{2}{|c|}{$\begin{array}{l}\text { Wilayah Penelitian } \\
\text { Menurut Dusun }\end{array}$}} & \multicolumn{3}{|c|}{ Jenis kegiatan yang dilakukan } & & \multirow[t]{2}{*}{ Jumlah } \\
\hline & & Usaha & Pedagang & Pedagang & & \\
\hline \multirow[t]{3}{*}{1.} & Papringan: & & & & & \\
\hline & Populasi & 10 & 87 & 13 & 110 & \\
\hline & Sampel & 7 & 21 & 7 & 35 & \\
\hline \multirow[t]{3}{*}{2.} & Samirono: & & & & & \\
\hline & Populasi & 10 & 66 & 17 & 93 & \\
\hline & Sampel & 7 & 28 & 9 & 44 & \\
\hline \multirow[t]{3}{*}{3.} & Mrican: & & & & & \\
\hline & Populasi & 7 & 28 & - & 90 & \\
\hline & Sampel & 3 & 25 & . & 28 & \\
\hline \multirow[t]{3}{*}{4.} & Sagan: & & & & & \\
\hline & Populasi & 4 & 22 & 5 & 31 & \\
\hline & Sampel & 4 & 18 & 5 & 27 & . \\
\hline \multirow[t]{3}{*}{5.} & Blimbingsari: & & & & & \\
\hline & Populasi & 1 & 9 & 5 & 15 & \\
\hline & Sampel & 1 & 9 & 5 & 15 & \\
\hline \multirow[t]{3}{*}{6.} & Kocoran: & & & & & \\
\hline & Populasi & 2 & 60 & - & 62 & \\
\hline & Sampel & 2 & 25 & . & 27 & \\
\hline \multirow[t]{3}{*}{7.} & Karangwuni: & & & & & \\
\hline & Populasi & 6 & 44 & 9 & 59 & \\
\hline & Sampel & 3 & 20 & 4 & 27 & \\
\hline \multirow[t]{3}{*}{8.} & Karanggayam: & & & & & \\
\hline & Populasi & 3 & 58 & 2 & 63 & \\
\hline & Sampel & 3 & 31 & 2 & 36 & \\
\hline \multirow[t]{6}{*}{9.} & Manggung: & & & & & \\
\hline & Populasi & 3 & 42 & 9 & 54 & \\
\hline & Sampel & 2 & 20 & 5 & 27 & \\
\hline & Jumiah: & & & & & \\
\hline & Populasi & 46 & 471 & 60 & 577 & \\
\hline & Sampel & 32 & 197 & 38 & 267 & \\
\hline
\end{tabular}




\section{Variabel Penelitian}

Dari 102 variabel yang dikumpulkan, pada garis besarnya dapat dipilah menjadi 5 komponen antara lain meliputi karakteristik penduduk dan pekerjaan, organisasi sosial, peran serta keluarga, intensitas jam kerja dan produktivitas, pendapatan serta pengaruh musim terhadap perubahan volume usaha.

Beberapa variabel pokok yang diteliti meliputi:

1. Karakteristik penduduk mencakup: perkawinan dan fcrtilitas, daerah asal, serta migrasi.

2. Pekerjaan mencakup: jenis usaha, mobilitas pekerjaan, jumlah pekerja, jumlah hari dan jam kerja, diversifikasi usaha dan tempat berjualan.

3. Peran serta keluarga mencakup: jumlah anggota keluarga, keterlibatan keluarga dalam usaha rumah tangga, dan sistem pembagian kerja.

4. Organisasi sosial: Keterlibatan dalam kegiatan sosial, organisasi usaha, ikatan dengan daerah asal dan organisasi lain yang serupa.

5. Produktivitas dan pendapatan meliputi modal usaha, pendapatan keluarga dan pendapatan clari usaha utama maupun tambahan.

\section{Analisis Data}

Sctelah data dari hasil wawancara di lapangan terkumpul kemudian dilakukan editing terhadap semua variabel dalam upaya untuk mendapatkan kualitas data yang baik. Tahap berikutnya aclalah melakukan koding clata yang kemudian dilanjutkan dengan pengolahan data. Berdasarkan kartu kode, yang tclah mewujudkan data dalam bentuk angka diproses lebih lanjut dengan komputer. Hasil keluaran komputer dengan program SPSS/PC+ diperoleh tabei frekuensi, untuk mengetahui sifat data dari segi distribusinya, sehingga diperoleh gambaran diskriptif.

Untuk melihat ada tidaknya hubungan dan menguji perbedaan antara dua variabel dipergunakan tabel silang. Metode statistik yang dipergunakan mean, uji perbedaan dan koefisiensi kontingensi. Dari analisis statistik ini diperoleh suatu generalisasi nilai ratarata, hasil uji perbedaan dan asosiasi hubungan dalam taraf yang paling se. derhana.

\section{Hambatan Dalam Penelitian}

Meskipun penelitian ini telah disiapkan sedemikian rupa masih dijumpai hambatan. Hambatan terscbut antara lain: (1) Penentuan waktu penelitian bertepatan pada musim penghujan, sedikit menghambat penelitian lapangan, (2) Tingginya mobilitas penduduk yang mempunyai usaha perdagangan pada sektor ekonomi skala kecil, menyebabkan kesulitan menemui responden untuk diwawancarai, (3) Jumlah jam kerja yang relatif panjang, menambah kesulitan wawancara dengan responden. Banyak di antara responden diwawancarai sambil mengerjakan pekerjaan yang dalam hal ini adalah melayani pembeli maupun menyiapkan barang dagangan.

Dari ketiga hambatan yang disebutkan di atas kesemuanya dapat diatasi, karena lokasi daerah penclitian itu sendiri berdekatan dengan tempat tinggal asisten lapangan. Hambatan yang bersifat teknis seperti pengecekan validitas dan reliabilitas data memang sulit untuk dilacak. Pendapatan dan jumlah jam kerja yang cukup panjang yang melibatkan banyak anggota keluarga tanpa dibayar menambah rumitnya perhitungan biaya produksi. 


\section{Deskripsi Wilayah Penelitian}

Pada bagian ini dibahas tentang wi. layah dalam hubungannya dengan ke. adaan demograsi dan sosial ekonomi. Ilal itu diperinci menurut jenis kegiatan dan pendapatan termasuk pula faktor-faktor yang mempengaruhinya seperti halnya jam kerja, jumlah peker. ja dan musim.

\subsection{Lokasi daerah}

Desa Caturtunggal merupakan salah satu wilayah Kecamatan De. pok, Sleman, Yogyakarta yang berbatasan dengan wilayah Kotamadya Yogyakarta (lihat Peta). Desa Caturtunggal terletak pada jalur jalan Yogyakarta - Surakarta dan Yogyakarta - Kaliurang. Karena letak desa ini di daerah pinggiran kota, maka hampir sepenuhnya terpengaruh oleh tata kehidupan kota. Sebagai akibatnya tata kehidupan masyarakat di daerah inipun tidak berbeda banyak dengan kehidupan kota Yogyakarta.

Luas wilayah Caturtunggal scki$\operatorname{tar} 11,04 \mathrm{~km}^{2}$ terdiri dari 20 pedusunan dan 6 rukun kampung (RK), berpenduduk 40728 jiwa (1986). Desa ini merupakan daerah dataran kaki gunungapi yang sebagian tanahnya bertekstur pasir bercampur lumpur berwarna coklat dengan daya serap cukup tinggi. Setiap pedusunan dan RK dapat dijangkau dengan kendaraan roda cmpat, sarana transportasi umum cukup baik seperti halnya adanya bus kota

\subsection{Pertambahan penduduk}

Laju pertumbuhan penduduk Caturtunggal selama tiga periode penunjukkan pertambahan semakin meningkat. Pertambahan penduduk periode 1961 - 1971 sekitar 2,8 persen per tahun, meningkat menjadi 5,7 persen per tahun pada periode 1971 - 1980, kemudian menjadi 7,8 persen per tahun pada periode 1980 - 1986. Diduga bahwa penyebab tingginya pertambahan penduduk tersebut adalah tingginya inigrasi masuk. Contoh kongkrit penyebab tingginya migrasi masuk ini didukung oleh banyaknya mahasiswa baru dari 15 perguruan tinggi yang berada di Caturtunggal yang sclalu bertambah dan separohnya tinggal di clacrah ini. Keadaan pen. duduk yang sclalu bertambah ini memerlukan faslitas kehidupan yang memadai

\subsection{Fasilitas desa}

Fasilitas Desa Caturtunggal sangat lengkap. Di wilayah ini ditempati 15 perguruan tinggi, 6 SLTA dan 7 SLTP. Fasilitas kesehatan ada 3 rumah sakit, kompleks pertokoan sepanjang Jalan Gejayan, Jalan Kaliurang dan Jalan Laksda Adisucipto. Selain itu ada 2 pasar dan 11 hotcl.

Dalam hubungannya dengan ke. giatan ekonomi penduduk, adanya berbagai fasilitas di atas mempunyai dampak terhadap perluasan kesempatan kerja dan kesempatan berusaha. Usaha rumah makan, pertokoan, warung baik menctap maupun dalam bentuk usaha rumah tangga dan pedagang keliling banyak dijumpai di daerah ini. Fasilitas pemondokan murah sampai mahal, demikian pula akomodasi hotel maupun fasilitas pendidikan di perguruan tinggi maupun sckolah menengah relatif didapatkan di Desa Caturtunggal. 


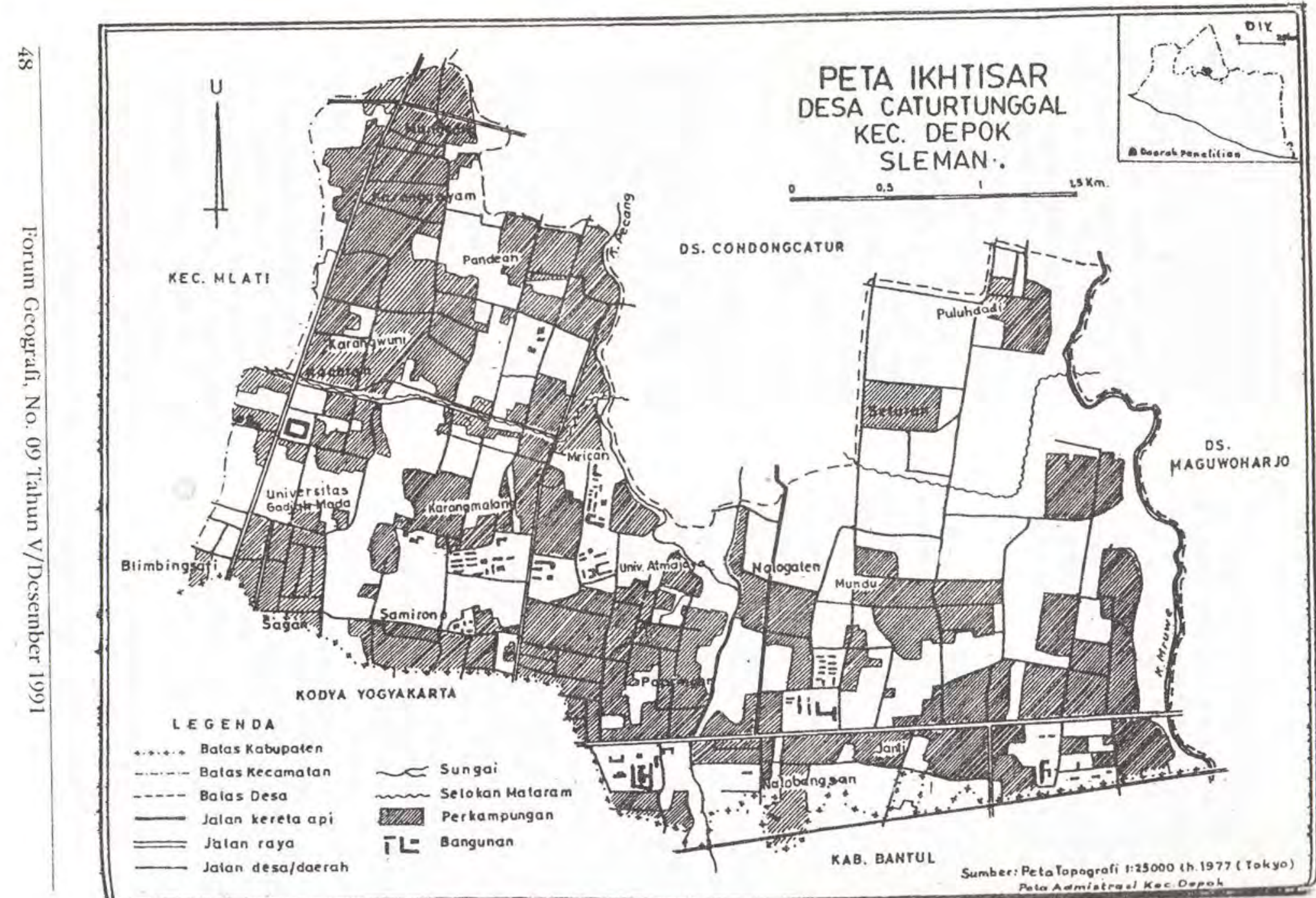


Fasilitas tempat inggal, seperti uransportasi, komunikasi, pelayanan seschatan, kantor pos, bank, angdutan kota, pasar, toko dan dokter praktek negeri maupun swasta’ menambah daya tarik pelajar dan mahasiswa dari luar Yogyakarta bersempat tinggal di Desa Caturtungal

\section{1 + Kegiatan ekonomi penduduk}

Keadaan wilayah Desa Caturtunggal dengan segala fasilitas yang ada meningkatkan kegiatan ekono. mi penduduk terutama pada sektor manufaktur dan jasa, mulai dari skala kecil sampai skala besar.

Pada usaha fasilitas wisata dan pacta pendatang di iesa Caturtunggal terdapat 11 buah hotel dan asrama mahasiswa, mulai dari yang berskala besar sampai kecil. Dari hotel yang ada, antara lain Hotel Ambarukmo, Sri Wedari, Sahid Garden Hotel, Puri Artha, Duta Widya dan masih banyak bentuk tempat tinggal lain bagi para pendatang. Dampak dari keadaan ini adalah pada kegiatan penduduk.

\section{Karakteristik Demografi dan Ke-} giatan Ekonomi

Analisis unit usaha perdagangan pada sektor ekonomi skala kecil ini dibedakan menjadi tiga, yaitu usaha rumah tangga, usaha menetap dan keliling. Selanjutnya dibahas menurut rincian karakteristik yang berikut.

2.1.Usia mulai bekerja dan jenis kela$\min$

Suatu hal yang menarik adalah usia mulai bekerja pada sub-sektor perdagangan skala kecil cukup rendah yaitu 16 tahun untuk pekerja perempuan dan 20 tahun untuk pekerja laki-laki. Hasil penclitian menunjukkan adanya kecenderungan bahwa pekerja pedagang keliling dan pedagang menetap rerata umurnya lebih muda daripada perdagangan usaha rumahtangga. Sekitar 73,7 persen dari pedagang keliling dan 50,3 persen dari pedagang menctap berumur kurang dari 20 tahun. Sebaliknya, pada perrdagang. an usaha rumah tangga sekitar 31,3 persen yang berumur kurang dari 20 tahun. Kecenderungan usia mulai bekerja yang relatif lcbih muda untuk pedagang usaha keluarga disebabkan pada awal mulanya mereka hanya membantu usaha keluarga, yang kemudian menjadi pekerja yang melepaskan diri dari usaha keluarga, disebabkan karena sejak usia dini sudah membantu ke. luarga, maka usia mulai bekerjapun relatif pada usia muda. 
Tahel 1. Usia Mulai Bekerja Mandiri

\begin{tabular}{lclll}
$\begin{array}{l}\text { Usia } \\
\text { mulai, } \\
\text { bekerja }\end{array}$ & $\begin{array}{l}\text { Usaha rumah } \\
\text { tangga }\end{array}$ & $\begin{array}{l}\text { Pedagang } \\
\text { menetap }\end{array}$ & $\begin{array}{l}\text { Pedagang } \\
\text { keliling }\end{array}$ & Jumlah \\
\hline$<14$ & 6,3 & 10,2 & 21,1 & 11,2 \\
$15-19$ & 25,0 & 40,1 & 52,6 & 40,1 \\
$20+$ & 68,8 & 49,7 & 6,3 & 48,7 \\
\hline Jumlah & 12,0 & 73,8 & 14,2 & 100 \\
$N$ & 32 & 197 & 38 & 267 \\
\hline
\end{tabular}

Berbeda halnya dengan yang bekerja sebagai pedagang keliling maupun pedagang menetap. Sebagian besar (74 persen) dari pekerja mengatakan bahwa menjadi pedagang menetap lebih pasti akan kelangsungan berusaha maupun pendapatan yang diperoleh. Meskipun demikian, untuk menjadi pedagang menetap diperlukan pengalaman berdagang yang biasanya diperoleh dari kegiatan usaha rumah tangga maupun pedagang keliling. Oleh sebab itu usia mulai bekerja sebagai pedagang menctap cenderung le. bih tua dibandingkan dengan pedagang keliling.

Hasil penelitian menunjukkan bahwa dua pertiga (61 persen) dari jumlah pekerja merupakan pekerja perempuan. Kegiatan mereka mengelompok pada usaha perdagangan yang dilakukan di luar rumah tangga akan tetapi tempat usahanya adalah menetap. Hanya sebagian kecil (31,6 persen) dari pekerja perempuan tersebut bekerja sebagai pedagang keliling. Diduga bekerja sebagai pedagang keliling memerlu. kan kekuatan fisik tertentu sebagai akibatnya kegiatan ini banyak dilakukan oleh pekerja laki-laki. 68,4 persen pekerja laki-laki memilih sebagai pedagang keliling dengan pertimbangan bahwa bekerja sebagai pedagang keliling lebih menguntungkan bila dibandingkan dengan kegiatan perdagangan yang lain.

Tabel 2. Jenis Kelamin Pekerja

\begin{tabular}{|c|c|c|c|c|}
\hline \multirow{2}{*}{$\begin{array}{l}\text { Ienis } \\
\text { kelamin } \\
\text { peker;a }\end{array}$} & \multicolumn{3}{|c|}{ Jenis kegiatan } & \multirow{2}{*}{ Jumlah } \\
\hline & $\begin{array}{l}\text { Usaha rumah } \\
\text { tangga }\end{array}$ & $\begin{array}{l}\text { Pedagang } \\
\text { menetap }\end{array}$ & $\begin{array}{l}\text { Pedagang } \\
\text { keliling }\end{array}$ & \\
\hline laki-laki & 21,9 & 36,0 & 68,4 & 39,0 \\
\hline P'crempuan & 78,1 & 64,0 & 31,6 & 61,0 \\
\hline Jumlah & 12,0 & 73,8 & 14,2 & 100 \\
\hline $\mathrm{N}$ & 32 & 197 & 38 & 267 \\
\hline
\end{tabular}




\section{Migrasi}

Hal yang menarik adalah hampir setengah ( 46 persen) dari penduduk yang bekerja pada sub sektor perdagangan skala kecil adalah penduduk pendatang, yaitu mereka yang berasal dari luar wilayah daerah Caturtunggal. Pada perdagangan usaha rumah tangga, sekitar dua pertiga (63 persen) dari mereka adalah pekerja bukan migran atau penduduk yang dilahirkan di daerah Caturtunggal. Keadaan ini dapat dimengerti karena perdagangan usaha rumah tangga dilakukan pada rumah tangga mereka adalah penduduk bukan kegiatan ekonomi. Oleh karena mercka ada. lah penduduk bukan migran, maka rumah yang digunakan sebagai tempat usaha bukan merupakan masalah. Hal seperti ini nampaknya berlaku pula untuk usaha perdagangan menetap, walaupun perbedaannya tidak begitu besar.

Tabel 3. Tempat Kelahiran

\begin{tabular}{|c|c|c|c|c|}
\hline \multirow{2}{*}{$\begin{array}{l}\text { Tempat } \\
\text { kelahiran }\end{array}$} & \multicolumn{4}{|c|}{ Jenis kegiatan } \\
\hline & $\begin{array}{l}\text { Usaha rumah } \\
\text { tangga }\end{array}$ & $\begin{array}{l}\text { Pedagang } \\
\text { menctap }\end{array}$ & $\begin{array}{l}\text { Pedagang } \\
\text { keliling }\end{array}$ & Jumlah \\
\hline Caturtunggal & 62,5 & 56,9 & 31,5 & 53,9 \\
\hline Luar Caturtunggal & 37.5 & 43,1 & 68,5 & 46,1 \\
\hline Jumlah & 12,0 & 73,8 & $1 / 1,2$ & 100 \\
\hline v & 32 & 197 & 38 & 267 \\
\hline
\end{tabular}

Nampaknya migran cenderung memilih melakukan usaha perdagangan keliling daripada perdagangan usaha rumah tangga maupun perclagangan menetap. Lebih dari dua pertiga ( 68 persesn) dari kegiatan perdagangan keliling dilakukan oleh migran. Diduga, sebagai akibat dari mahalnya akan harga rumah, migran hanya menyewa rumah yang tidak begitu luas, dan tidak memungkinkan scbagai tempat berusaha. Dapat pula disebabkan karena scbagai migran, apalagi migran yang tidak bersama keluarga, tempat tinggal di dacrah penelitian tidak pada wilayah stratcgis untuk berjualan menctap, maka menjajakan dagangan secara berkeliling adalah pilihan yang terbaik.
Dapat pula terjadi karena mereka adalah pendatang sengaja menghindari persaingan langsung dengan pedagang usaha rumah tangga atau pedagang menetap dimana tempat berusaha sudah menetap, maka berdagang keliling merupakan strategi untuk menclapatkan jumlah konsumen baru sebanyak mungkin dengan daya jangkau wilayah pemasaran yang cuku luas.

Bila diperhatikan arah dari dacrah asal migran ada suatu hal yang incnarik. Hanya 13 persen dari migran pc. dagang keliling berasal clari Kabupaten Sleman (di luar wilayah Caturtunggal). Lebih dari setengah (75 persen) adalah migran dari wilayah Kabupaten Bantul dan sisanya sckitar sepertiga (29) per- 
sen) justru berasal dari wilayah Kotamadya Yogyakarta, justru lokasinya bersinambungan dengan daerah penelitian. Migran pekerja usaha perdagangan keliling didominasi dari daerah Bantul diduga karena semakin terbatasnya kesempatan kerja di daerah mereka sendiri. Mereka melakukan mobilitas ke daerah-daerah pinggiran kota yang tidak begitu jauh dari daerah asal. Tumbuhnya wilayah-wilayah permukiman baru, menumpuknya kawasan pemondokan pelajar-mahasiswa dapat ikut andil sebagai penyebabnya. Akan tctapi mengapa migran dari Kotamadya tidak begitu banyak jumlahnya. Mungkin saja mereka lebih tertarik berusaha di wilayahnya sendiri daripada harus melakukan mobilitas atau migran dari Bantul dan wilayah lainnya merasa kesempatan kerja usaha perdagangan kecil di Kotamadya sangat terbatas.

\subsection{Upaya mendapatkan pekerjaan dan mobilitas}

Hasil penelitian menunjukkan bahwa lebih dari setengah ( 56 persen) dari mereka mengatakan bahwa pekerjaan yang dilakukan pada saat penelitian, merupakan upaya sendiri tanpa harus melibatkan orang lain untuk mendapatkannya. Ini memberi kesan bahwa kesempatan kerja pada sub sektor perdagangan kecil masih tersedia cukup besar, sebab tanpa harus melibatkan peran orang lainpun berhasil mendapatkan atau menciptakan pekerjaan se. bagai pedagang menetap maupun pedagang usaha rumah tangga. Sebagian besar dari mereka adalah pekerja bukan migran. Untuk pekerja migran sekitar dengan cara mengikuti atau ma. gang dari orangtua mereka. Kebanyakan dari pekerja tersebut adalah sebagai pedagang keliling. Suatu pernyataan yang belum dapat dijawab dalam penelitian ini adalah mengapa mereka harus melakukan magang dahulu hanya untuk bekerja sebagai pedagang keliling?

Tabel 5. Cara Mendapatkan Pekerjaan

$\begin{array}{lllll}\begin{array}{l}\text { Cara } \\ \text { mendapatkan } \\ \text { pekerjaan }\end{array} & \begin{array}{l}\text { Jenis kegiatan } \\ \text { Usaha rumah } \\ \text { tangga }\end{array} & \begin{array}{l}\text { Pedagang } \\ \text { menetap }\end{array} & \begin{array}{l}\text { Pedagang } \\ \text { keliling }\end{array} & \text { Jumlah } \\ \begin{array}{l}\text { Usaha sendiri } \\ \text { Ikut orangtua } \\ \text { atau saudara }\end{array} & 59,4 & 58,9 & 36,8 & 55,8 \\ & 40,6 & 41,1 & 63,2 & 14.2 \\ \text { Jumlah } & 12,0 & 73,8 & 14,2 & 100 \\ \mathrm{~N} & 32 & 197 & 38 & 267\end{array}$

Pada kegiatan sub-sektor perdagangan kecil diduga bahwa frekuensi ganti pekerjaan adalah cukup besar. Ini disebabkan karena sebagian besar dari kegiatan tersebut diperoleh secara mandiri dalam arti pekerjaan tersebut diciptakan sendiri. Oleh sebab itu kemungkinan untuk berganti pekerjaan semestinya cukup tinggi. Hasil penelitian menunjukkan hal yang sama se- 
kitar 60 persen dari pekerja mengatakan pernah mengalami berganti pekerjaan. Ini berarti mobilitas pekerjaan mi discbabkan karena pekerjaan yang dilakukan merupakan pekerjaan bukan yang pertama kali. Keadaan ini didukung informasi bahwa perbedaan antara usia pekerja pada saat penelitian dilaksanakan dengan usia mulai bekerja yang pertama kali cukup besar. Demikian pula rata-rata usia pekerja yang mengatakan pernah berganti pekcrjaan dengan yang belum pernah ganti pekerjaan cukup besar, yaitu 23 tahun untuk yang pernah ganti pekerjaan dengan 20 tahun untuk yang belum pernah ganti pekerjaan. Kemudian, bila diperhatikan menurut tempat/lokasi berusaha, persentase pedagang keliling yang pernah berganti pekerjaan adalah 76 persen bila dibandingkan dengan pedagang menetap yang hanya 57 persen. Tingginya persentase mobilitas pekerjaan pada pedagang keliling dapat disebabkan karena tidak adanya ketentuan yang pasti keharusan untuk berusaha bila dibandingkan dengan pedagang menetap.

Tabel 6. Mobilitas Pekerjaa

\begin{tabular}{|c|c|c|c|c|}
\hline \multirow{2}{*}{$\begin{array}{l}\text { Mobilitas } \\
\text { pekeriaan }\end{array}$} & \multicolumn{4}{|c|}{ Jenis kegiatan } \\
\hline & $\begin{array}{l}\text { Usaha rumah } \\
\text { tangga }\end{array}$ & $\begin{array}{l}\text { Pedagang } \\
\text { menctap }\end{array}$ & $\begin{array}{l}\text { Pedagang } \\
\text { keliling }\end{array}$ & fumlah \\
\hline Penah ganti pekérjaan & 62,5 & 36,9 & 76,3 & 60,3 \\
\hline $\begin{array}{l}\text { Tidak pemah ganti } \\
\text { pekerjaan }\end{array}$ & 37.5 & 43,1 & 23.7 & 39,7 \\
\hline Jumlah & 12,0 & 73.8 & 14,2 & 100 \\
\hline N & 32 & 197 & 38 & 267 \\
\hline
\end{tabular}

\subsection{Keterlibatan anggota rumah tang- ga}

Beberapa hasil penelitian sebclumnya menunjukkan bahwa pada kegiatan ekonomi skala kecil, keterlibatan anggota keluarga cukup besar. Mereka merupakan pekerja keluarga tanpa dibayar. Status dari pekerja ini biasanya membantu usaha keluarga. Hasil penelitian menunjukkan hal yang sama, scbagian besar (77 persen) dari anggota

keluarga mengatakan terlibat dalam kcgiatan ekonomi rumah tangga. Untuk usaha rumah tangga dan perdagangan menetap hampir semua kegiatan tersebut dibantu oleh anggota rumah tangga. Sebaliknya untuk pedagang ke. liling cukup rendah memanfaatkan pekerja keluarga. Hanya 53 persen clari pedagang keliling yang mengatakan dibantu oleh pekerja keluarga. 
Tabel 7. Keterlibatan Anggota Keluarga

\begin{tabular}{|c|c|c|c|c|}
\hline \multirow{3}{*}{$\begin{array}{l}\text { Ketcrlibatam anggota } \\
\text { kcluargà }\end{array}$} & \multirow{3}{*}{$\begin{array}{l}\text { Isaha rumah } \\
\text { tangga }\end{array}$} & \multicolumn{2}{|c|}{ Jenis kegiatan } & \multirow{3}{*}{ Jumlah } \\
\hline & & Pedagang & Pedagang & \\
\hline & & menetap & keliling & \\
\hline Adat yang terlibat & 84,4 & 80,2 & 52,6 & 76,8 \\
\hline Tidak ada & 15,6 & 19,8 & 47,4 & 23,2 \\
\hline Jumlah & 12,0 & 73,8 & 14,2 & 100 \\
\hline $\mathrm{N}$ & 32 & 197 & 38 & 267 \\
\hline
\end{tabular}

Rendahnya keterlibatan anggota ke. luarga pada usaha perdagangan keliling disebabkan sebagian besar dari mereka adalah migran tidak dengan anggota keluarga, yang mcnurut mereka lebih populer dengan bujang lokal (bulog). Dengan demikian, kebanyakan dari pedagang keliling terscbut adalah pekerja mandiri, dalam arti semua aktivitas dikerjakan sendiri tanpa bantuan orang lain. Kemudian, dari pedagang keliling yang dibantu oleh anggota keluarga, jumlah yang membantu biasanya tidak banyak bila dibandingkan dengan kegiatan usaha rumah tangga maupun pedagang menctap.

Tabel 8. Jumlah Anggota Keluarga Yang Berpartisipasi

\begin{tabular}{|c|c|c|c|c|}
\hline \multirow{3}{*}{$\begin{array}{l}\text { Jumlah anggota } \\
\text { kcluarga }\end{array}$} & \multicolumn{4}{|c|}{ Jenis kegiatan } \\
\hline & lisaha rumah & Pedagang & Pedagang & Jumlah \\
\hline & langga & menetap & kcliling & \\
\hline satu orang & 28,1 & 31,5 & 60,1 & 37.5 \\
\hline dua orang & 37,5 & 5()$, 3$ & $3 / 4,1$ & 46,4 \\
\hline tiga orang atau lebih & 34,4 & 15,2 & 5,8 & 16,1 \\
\hline Iumlah & 13,2 & 77,1 & 9,7 & 100 \\
\hline$N$ & 27 & 158 & 20 & 205 \\
\hline
\end{tabular}

Dari kegiatan ekonomi perdagangan skala kecil yang melibatkan anggota keluarga, hanya sekitar 38 persen yang melibatkan seorang anggota keluarga, 46 persen mengatakan melibatkan dua anggota keluarga dan sekitar 16 persen yang dibantu olch tiga anggota keluarga dan lebih. Sekitar dua pertiga (60 persen) dari pedagang keliling hanya dibantu oleh seorang anggota keluar- ga, dan hanya sebagian kecil (6 persen) yang dibantu olch tiga anggota ke. luarga dan lebih. Di lain pihak, untuk usaha rumah tangga, sckitar sepertiga (34 persen) yang mengatakan dibantu oleh tiga anggota keluarga dan lebih. Keterlibatan anggota keluarga pada perdagangan menetap tidak jauh berbeda dengan usaha rumah tangga, meskipun sebagian besar hanya meli- 
batkan dua anggota keluarga. Hanya saja ada kecenderungan semakin banyak anggota keluarga yang terlihat tidak menunjukkan kecenderungan akan bertambahnya pendapatart.

\section{Penghasilan, Jam Kerja dan Pen- didikan}

Dalam sub bab ini dibahas seberapa jauh penambahan jam kerja dan jumlah pekerja akan meningkatkan penghasilan para pedagang pada ekonomi skala kecil. Selain itu bagaimana peranan pendidikan terhadap jumlah pekerja di sektor perdagangan pada ekonomi skala kecil.

Gambaran umum, bahwa dengan penambahan jam kerja sescorang atau sejumlah orang pekerja akan mendapatkan penghasilan yang meningkat. Demikian pula halnya dengan penambahan jumlah pekerja akan meningkatkan penghasilan dari suatu usaha. Asumsi yang demikian tidak sepenuhnya berlaku di sektor perdagangan pada ekonomi skala kecil, karena beberapa keterbatasan. Keterbatasan tersebut dapat diamati dari jenis barang yang diperdagangkan yang biasanya monoton tidak terdapat variasi. Pemupukan modal pada sektor ini terbatas, karena usaha ini dilakukan tanpa managemen yang terpisah dengan kebutuhan hidup rumah tangga mereka sehari-hari. Pcngeluaran untuk kebutuhan hidup rumah tangga akan meningkat bilamana ada peningkatan penghasilan, kadangkadang bisa terjadi menurunnya modal usaha karena pengeluaran rumah tangga yang tidak terkenclali.
Peranan pendidikan pada usaha perdagangan ekonomi skala kecil relatif sangat rendah, karena sifat pekerjaan yang ditangani sebagian besar tidak memerlukan ketrampilan dan pendidikan khusus. Namun demikian secara berkelompok, berkaitan dengan tenaga kerja keluarga, bagi para pedagang yang berpendidikan akan membatasi keterlibatan seluruh keluarga secara penuh, mengingat kepentingan masa depan anak-anak mereka.

\subsection{Hubungan antara jam kerja de- ngan penghasilan}

Kegiatan perdagangan skala kccil seringkali dipengaruhi olch musim. Musim sepi, musim biasa dan musim ramai tidak hanya discbabkan oleh perubahan musim hujan dan kemarau saja, akan tetapi fluktuasi penerimaan dan penggunaan yang ada pada masyarakat. Apabila hal ini terjadi pada masyarakat dan berpengaruh terhadap pola konsumsi, strategi apa saja yang mercka pilih untuk menyesuaikan keadaan yakni jumlah konsumen yang akan dicapai Cukup berhasilkah, bilamana mereka menggunakan strategi memperpanjang jumlah jam kerja untuk menjaring scjumlah target konsumen tertentu schubungan dengan sejumlah target pendapatan yang diharapkan. Bilamana strategi memperpanjang jumlah jam kerja yang dipilih apakah hal ini tidak berpengaruh pada rerata pendapatan per satuan jam kerja. 
Tabel 9. Ilubungan Antara Jam Kerja Dengan Penghasilan

\begin{tabular}{lllcr}
$\begin{array}{l}\text { Pendapatan seminggu } \\
\text { (Rupiah) }\end{array}$ & $<34$ & \multicolumn{3}{l}{ Jumlah Jam Kerja Seminggu } \\
& & $35-64$ & $65+$ & Jumlah \\
\hline 10.000 & 35,4 & 30,1 & 30,5 & 25,8 \\
$10.000-15.000$ & 34,3 & 37,8 & 30,3 & 42,7 \\
$>15.000$ & 30,3 & 32,1 & 39,2 & 31,5 \\
Jumlah & 25,8 & 32,9 & 41,3 & 100 \\
$\mathrm{~N}$ & 69 & 88 & 110 & 267 \\
\end{tabular}

Dari data tersebut menunjukkan pola yang tidak jelas hubungan antara jumlah jam kerja dengan pendapatan. Nampaknya jumlah jam kerja yang sangat panjang yaitu pemanfaatan pekerja yang berlebih tidak diikuti dengan penambahan pendapatan. Meskipun ada kecenderungan adanya perbedaan penclapatan menurut jam kerja akan tetapi perbedaan tersebut sangat rendah dan hampir tidak berarti, menurut penambahan satuan waktu jam kerja dengan perubahan pendapatan.

Keadaan ini discbabkan karena jenis usaha maupun jumlah barang dagangan ikut mempengaruhi pula. Mereka tidak berani selalu mengambil spekulasi untuk menambah modal dagangan. Justru dengan menambah modal harus menambah jumlah jam kerja agar dagangan tersebut habis. Oleh sebab itu, justru dengan jumlah jam kerja yang cukupan saja kemungkinan tidak rugi atau mendapatkan sedikit keuntungan justru dapat tercapai. Pengalaman menunjukkan bahwa dengan jumlah dagangan yang sama akan tetapi dapat habis pada waktu yang relatif lebih singkat biasanya scjumlah keuntungan mudah didapat. Olch sebab itu, nampaknya jumlah jam kerja yang panjang lebih tepat dikatakan merupakan strategi untuk tidak mengalami kerugian daripada mengejar scjumlah target keuntungan.

3.2Hubungan antara penghasilan dengan keterlibatan keluarga

Salah satu ciri pokok kegiatan ekonomi skala kecil adalah bersifat padat karya dalam arti banyak melibatkan pekerja dalam usaha yang dilakukan. Sering pula discbut sebagai kegiatan yang banyak menggunakan atau memanfaatkan pekerja setengah penganggur. Dalam hubungan antara jumlah pekerja dengan penghasilan menjadi lidak menentu, karena ketcrlibatun anggota keluarga. Dapat saja, pertambahan jumlah anggota keluarga yang terlibat tidak scjalan dengan kenaikan pendapatan yang diperoleh. 
Tabel 10. Hubungan Antara Pendapatan Dengan Keterlibatan Keluarga

\begin{tabular}{|c|c|c|c|c|}
\hline \multirow{2}{*}{$\begin{array}{l}\text { Jumlah anggota } \\
\text { yang terlibat }\end{array}$} & \multicolumn{3}{|c|}{ Jumlah penghasilan seminggu (rupiah) } & \multirow[b]{2}{*}{ Jumlah } \\
\hline & $<10.000$ & $\begin{array}{l}10.000 \\
15.000\end{array}$ & 15.000 & \\
\hline 1 & 35,6 & 25,6 & 20,0 & 37.5 \\
\hline 2 & 31,2 & 36,1 & 37,3 & 46,4 \\
\hline $3+$ & 32,4 & 38,3 & 42,7 & 16,1 \\
\hline Jumlah & 25,8 & 42,7 & 31,5 & 100 \\
\hline$N$ & 69 & 114 & 84 & 267 \\
\hline
\end{tabular}

Hasil penelitian mengungkapkan bahwa ada kecenderungan semakin tinggi pendapatan semakin banyak menggunakan pekerja keluarga. Meskipun kecenderungan tersebut baik demikian besar, akan tetapi pertambahan pendapatan yang diperoleh dengan harus menambah pekerja memberikan kesan bahwa perluasan kesempatan kerja mudah didapat bagi yang sudah mempunyai usaha. IIal yang menarik bahwa perluasan kesempatan berusaha dengan menambah pekerja diikuti dengan kenaikan pendapatan. Namun demikian apabila diamati lcbih rinci tentang kenaikan pendapatan dengan pertambahan pekerja, maka perubahan tersebut dapat dikatakan tidak ada artinya. Perbanding. an antara rata-rata pendapatan seminggu untuk ketiga kelompok tersebut tidak cukup besar.

PersoalanPersoalan pokok bagi pekerja pada kegiatan ekonomi skala kecil adalah antara memperluas usaha dengan harus menam. bah anggota keluarga atau pekerja lain terlibat untuk mendapatkan sedikit kenaikan pendapatan. Di lain pihak mereka juga dihadapkan pada suatu kenyataan bahwa upaya yang akan dilakukan untuk mem. perluas usaha tersebut tidak akan membawa banyak perubahan pen. dapatan menurut jumlah pekerja yang terlibat. Adalah wajar seperti yang dijumpai di dacrah penelitian bahwa besarnya usaha yang ada su. lit diperluas atau dikembangkan. Andaikan terjadi perubahan permintaan akan suatu barang, jumlah permintaan tersebut tidak demikian besar. Dampaknya adalah usaha yang dilakukan akan sulit berkembang dalam hal kenaikan pendapatan per kapita bukan pada kescmpatan kerja.

\subsection{Hubungan antara pendidikan de- ngan keterlibatan keluarga}

Hal yang menarik bahwa sekitar 52 persen dari tenaga kerja perdagangan skala kecil berpendidikan Sekolah Dasar dan lebih. Bahkan sepertiga (37 persen) dari mereka berpendidikan Sekolah lanjutan Pertama dan lebih. Ini berarti kualitas pekerja pada kegiatan perdagangan kecil cukup tinggi. Bila diperhatikan pendidikan yang dicapai oleh pekerja menurut jenis usaha, ada hal yang menarik. Pekerja pada 
perdagangan usaha rumah tangga dan perdagangan keliling lebih berpendidikan daripada pekerja me- netap, meskipun usia pekerja pedagangan keliling cenderung lebih muda.

Tabel 11. Hubungan Antara Pendidikan Dengan Keterlibatan Keluarga

\begin{tabular}{|c|c|c|c|c|c|}
\hline \multirow{2}{*}{$\begin{array}{l}\text { Jumlah } \\
\text { keluarga } \\
\text { yang terlibat }\end{array}$} & \multirow[b]{2}{*}{$\mathrm{SD}_{1 \cdot 3}$} & \multicolumn{4}{|c|}{ Pendidikan yang ditamatkan } \\
\hline & & $\mathrm{SD}_{4-6}$ & SMP & $\operatorname{SMA}$ & Jumiah \\
\hline 1 & 21,2 & 20,4 & 40,3 & 50,7 & 37,5 \\
\hline 2 & 35,4 & 31,2 & 28,2 & 29,2 & 46,4 \\
\hline $3+$ & 56,6 & 48,4 & 31,2 & 20,1 & 16,1 \\
\hline fumlah & 29,2 & 17,6 & 26,6 & 26,6 & 100 \\
\hline$N$ & 78 & 47 & 71 & 71 & 267 \\
\hline
\end{tabular}

Tabel di atas mencoba melihat keterlibatan anggota keluarga yang men. cari nafkah menurut pendidikan pekerja. Dasar asumsinya adalah semakin tinggi pendidikan pekerja semakin rendah keterlibatan anggota keluarga dalam mencari nafkah. Ini discbabkan ka. rena pada yang berpendidikan tinggi diasumsikan keadaan ekonomi rumah langga lebih mampu daripada yang ekonominya lemah. Hasil penelitian menunjukkan bahwa semakin tinggi pendidikan pekerja perdagangan skala kecil semakin rendah keterlibatan ang. gota keluarga dalam mencari nafkah. Pada pekerja berpendidikan Sekolah Dasar clan yang lebih rendah lagi, sekitar setengah $(52,7$ persen) mengatakan yang membantu mencari nafkah aclalah tiga anggota keluarga dan lebih. Kemudian, pada pendidikan Sekolah Menengah Pertama dan Sekolah Menengah Atas hanya sekitar scperempat saja dari mereka yang mengatakan dibantu oleh tiga anggota keluarga dalam mencari nafkah.

Bagi yang melibatkan anggota keluarga dalam mencari nafkah pada pe- kerja berpendidikan Sekolah Menengah Pertama ( 40,3 persen) maupun Menengah Atas ( 50,7 persen) cukup tinggi, sebaliknya untuk yang berpendidikan Sekolah Dasar adalah rendah sekali yaitu sekitar 20 persen. Ini berarti ada hubungan negatip antara pendidikan dengan keterlibatan anggota keluarga dalam mencari nafkah. Mendasarkan asumsi yang telah disebutkan sebelumnya, hasil penelitian mengung. kapkan bahwa pada pekerja yang relatif lebih mampu dalam hal ini adalah lebih berpendidikan justru kurang memanfaatkan pekerja keluarga yang ada Keterlibatan anggota keluarga dalam mencari nafkah yang rendah ini dapa discbabkan pula karena jenis usaha yang dilakukan tidak memerlukan ketrampilan khusus.

\section{Kesimpulan}

Kegiatan pekerja di sektor perdagangan pada ekonomi skala kecil memang cukup rumit. Meskipun yang dilakukan cukup sederhana, namun un. 
tuk mengukur intensitas jam kerja pada setiap unit usaha cukup sulit, schingga tidak dapat sepenuhnya menerangkan produktivitas dan penghasilan. Para pekerja di sektor perdagangan kebąnyakan terdiri dari pekcrja keluarga, menciptakan lapangan kerja sendiri. Dalam hal mendapatkan modal usaha, memilih jenis usaha dan pemasaran hasil produksi juga dilakukan secara mandiri.

Seperti pada usaha penduduk pada ekonomi skala kecil lainnya, usaha di sektor perdagangan ini cenderung padat karya dan diikuti olch jam kerja yang panjang, namun kadang-kadang keteraturannya rendah. Kebanyakan dari mereka belum mempunyai ren. cana pengembangan usaha yang dijalankan.

Hasil penelitian mengungkapkan bahwa hampir separo pekerja pacla usaha perdagangan pada ckonomi skala kecil adalah para pendatang. Dua pertiga pekerja pada usaha perdagangan ini terdiri dari wanita dan sebagian besar dari mereka mengelompok pada usaha perdagangan menctap dan usaha rumah tangga. Usia mulai bekerja pedagang menetap lebih tua dibandingkan dengan usaha rumah tangga dan pedagang keliling. Di antara usaha perdagangan pada ekonomi skala kecil usaha menetap dan rumah tangga $k$ bih didominir olch pekerja non migran, masing-masing sekitar dua pertiga. Usaha perdagangan keliling lebih didominir oleh para migran ( 68 per- sen)

I Ial yang menarik bahwa latar belakang pendidikan formal mercka cukup tinggi. Sekitar 47 persen dari pekerja tersebut berpendidikan Sekolah Menengah Pertama dan Menengah Atas. Diduga sebagai akibat terbatasnya kesempatan kerja maka keticlaksesuaian pendidikan dengan pekerjaan muncul kembali. Sebagai akibat dari latar belakang pendidikan yang cukup tinggi tersebut, keterlibatan anggota keluarga dalam upaya mencari nafkah tidak se. demikian besar. Hal ini dapat disebabkan skala usaha yang dilakukan adalah kecil dan tidak memcrlukan pekerja yang besar sekalipun pekerja keluarga.

Walaupun ada kecenderungan pertambahan jumlah pekerja dapat menaikkan jumlah pendapatan, akan tetapi bila dihitung rerata pendapatan menurut jumlah pekerja yang tcrlibat, justru tidak merubah status ekonomi. Justru yang terjadi adalah rerata pendapatan mereka aclalah tetap. Kemudian, hasil penelitian mengungkapkan bahwa tidak ditemukan hubungan antara jumlah jam kerja dengan pendapatan. Nampaknya, jumlah jam kerja yang panjang adalah merupakan strategi untuk tidak mengalami kerugian daripada mendapatkan keuntungan. Tidak ada pilihan lain kecuali memperpanjang jam kerja untuk tidak mengalami kerugian, dan scmakin panjang jam kerja berarti kemungkinan untuk mengalami kerugian semakin besar. 


\section{DAFTAR PUSTAKA}

Adi Saseno, 1985. Sistem Pembinaan Sektor Informal. Dalam: Lokakarya Pembinaan Sektor Informal. Jakarta: Departemen Depnaker \& Kantor Menteri Negara KLH, 6-8 Pebruari 1985.

Dawam Rahardjo, 1983. Situasi Pekerjaan, Setengah Pengangguran dan Kesempatan Kerja Di Sektor Perdagangan. Paper pada Lokakarya Nasional Angkatan Kerja dan Kesempatan Kerja (Jakarta).

Forbes, D.K., 1981. Petty Commodity Production and Underdevelopment: The Case of Peddlers and Trshaw Riders in Ujung Pandang, Indonesia. Dalam: Program in Planning. vol. 16, pp. 113-123.

Fricdman \& Sullivan. 1974. The Absorption of Labour in the Urban Economy. The Case of Developinent Countries. Dalam: Economic Development and Cultural Change. No. 3 , pp. $385-413$.

Hart, Keith. 1973. Informal Income Opportunities and Urban Employment in Ghana. Dalam: Journal of Modern African Studies. 11 (1):pp. 61-89)

Harle, Peter, 1983. Sektor Informal: Ekonomi Survival di Kota-kota Metropolitan Dunia Ketiga. Dalam: Galang. Jakarta: Pusat Dokumentasi \& Informasi Scktor Informal, no. 1 Th. $1 / 1983$, pp. 23.29.

Hidayat, 1983. Definisi dan Evaluasi Sektor Informal. Dalam: Galang. Ibid, pp. 7-15.

Juliasar An-Naf, 1983. Pedagang Kaki Lima Dengan Berbagai Segi Persoalannya. Dalam: Galang. Jakarta: Pusat Dokumentasi dan Informasi Sektor Informal, No. 1 Th. $1 / 1983$, pp. $30-39$.

Manning, Chris, Tadjudin Noor Effendi dan Tukiran. 1982. Struktur Pekerjaan Sektor Informal dan Kemiskinan Di Kota. Sebuah Studi Kasus Di Diraprajan Yogyakarta. Yogyakarta: Makalah Seminar PPSK- UGM.

Middleton, Alan, 1983. Petty Manufacturing, Capitalist Enterprises and the Process of Accumulation in Ecuador. Dalam: BIES, Vol. XIII, pp. 506-524

Moser, Caroline O.N. 1978. Informal Sector of Petty Commodity Production: Dualism or Dependence in Urban Development. Dalam: World Development, Vol. 6, No. 9/10. pp. 1041-1064.

Mulyanto Sumardi \& Hans-Dicter Evers, ed., 1982. Kemiskinan dan Kebutuhan Pokok. Jakarta: Yayasan Ilmu-ilmu Sosial, CV. Rajawali.

Sudarsono Km: 1982. Tinjauan Angkatan Kerja di Indonesia. Yogyakarıa: Makalah Seminar di Fakultas Geografi UGM.

..... 1986. Penyerapan Angkatan Kerja Migran Pada Sektor Ekonomi Skala Kecil di Kecamatan Gondokusuman, Kotamadya Yogyakarta. Tesis Program Studi Fakultas Pasca Sarjana UGM.

Suwarto, 1981. Perilaku Berbelanja Penduduk Kotamadya Yogyakarta. Yogyakarta: Skripsi Sarjana Fakultas Geografi UGM.

Tadjuddin Noer Effendi, 1982. Kesempatan Kerja Sektor Informal di Daerah Perkotaan Indonesia. Yogyakarta: Seminar Pembinaan Kegiatan llmiah Masyarakat Akademi, Fakultas Geografi UGM. 
Tim Fakultas Geografi UGM, 1989. Produktivitas Kegiatan Penduduk Pada Sektor Ekonomi Skala Kecil Di Kelurahan Caturtunggal, Depok, Sleman. Yogyakarta: Fakultas Geografi UGM.

Trisura Suradi, 1983. Kesempatan Kerja Di Sektor Industri. Paper Pada Lokakarya Nasional Angkatan Kerja dan Kesempatan Kerja. (Jakarta). 